\title{
PERENCANAAN DAUR ULANG AIR LIMBAH NON KAKUS PADA PUSAT PERBELANJAAN PLAZA SLIPI JAYA
}

\author{
Jumiah, LT. Simbolon, Rosmawita
}

\begin{tabular}{|c|c|c|c|c|}
\hline \multicolumn{5}{|c|}{ Abstrak } \\
\hline \multirow{3}{*}{\multicolumn{5}{|c|}{$\begin{array}{l}\text { Perencanaan ini bertujuan untuk menentukan teknologi daur ulang air limbah dan mendapatk } \\
\text { hasil perhitungan dimensi dari instalasi daur ulang air limbah non kakus pada Plaza Slipi Ja) } \\
\text { Teknik perencanaan berpedoman pada teori yang ada dan hasil penelitian yang pern } \\
\text { dilakukan oleh Warjiyo, ST dan Amalia, S.Pd dengan judul " Instalasi Pengolahan Air Limb }\end{array}$}} \\
\hline & & & & \\
\hline & & & & \\
\hline \multicolumn{5}{|c|}{ Rumah Tangga Non Kakus untuk Keperluan MCK pada Daerah yang Mengalami Kekeringan $\mathrm{f}$} \\
\hline \multirow{2}{*}{\multicolumn{5}{|c|}{$\begin{array}{l}\text { Debit air hasil daur ulang di Plaza Slipi Jaya sebesar } 70,1 \mathrm{~m}^{3} / \text { hari. Daur ulang ini da } \\
\text { mengurangi penggunaan air PDAM sebesar } 47,69 \% \text {. Dimensi Instalasi Daur Ulang Air Limb }\end{array}$}} \\
\hline & & & & \\
\hline 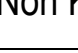 & & & & \\
\hline No & Jenis & Panjang(m) & Lebar(m) & Tinggi(m) \\
\hline 1 & Bak Penampung Air Limbah & 4 & 2 & 5,5 \\
\hline 2 & Bak Saringan Kasar & 2,6 & 1,3 & 4 \\
\hline 3 & Bak Koagulasi & 4 & 2 & 5,5 \\
\hline 4 & Bak Flokulasi & 4 & 2 & 5,5 \\
\hline 5 & Bak Sedimentasi & 10 & 5 & 8 \\
\hline 6 & Bak Filtrasi & 10 & 5 & 8 \\
\hline 7 & Bak Effluent & 18 & 9 & 12,5 \\
\hline
\end{tabular}

Sedangkan air hasil daur ulang memenuhi standar Baku Mutu Kualitas Air Kelas IV menurut Peraturan Pemerintah No. 82 tahun 2002 tentang Pengelolaan Kualitas Air dan Pengendalian Pencemaran Air, dengan data sebagai berikut :

\begin{tabular}{|c|l|c|c|c|c|}
\hline No & Parameter & Satuan & Maks yang Diperbolehkan & Influent & Effluent \\
\hline 1 & BOD & $\mathrm{Mg} / \mathrm{l}$ & 12 & 42,7 & 8,96 \\
2 & $\mathrm{COD}$ & $\mathrm{Mg} / \mathrm{l}$ & 100 & 51,2 & 20,48 \\
3 & TSS & $\mathrm{Mg} / \mathrm{l}$ & 400 & 383 & 114,9 \\
\hline
\end{tabular}

Sehingga dapat disimpulkan bahwa air hasil daur ulang air limbah non kakus di Plaza Slipi Jaya dapat dimanfaatkan untuk penggelontor(flushing) dan penyiram tanaman. 


\section{PENDAHULUAN}

Air merupakan kebutuhan utama bagi makhluk hidup di bumi ini. Walaupun bumi sebagian besar terdiri atas air, namun ironisnya masih ada sebagian masyarakat yang kekurangan air. Hal ini banyak terjadi di kota besar khususnya di ibukota negara yaitu Jakarta.

Perkembangan perekonomian dan industri dibarengi pula dengan pesatnya laju urbanisasi akan menimbulkan degradasi(penurunan) lingkungan yang pada hakekatnya merupakan pemicu berbagai masalah lingkungan, seperti pencemaran air yang akan menurunkan kualitas hasil pembangunan itu sendiri. Demikian pula dengan pembangunan pusat perbelanjaan yang semakin marak di Jakarta. Hampir setiap hari masyarakat Jakarta mengunjungi pusat perbelanjaan atau yang disebut mall, yaitu tempat untuk pemenuhan hampir semua kebutuhan masyarakat ataupun hanya sekedar untuk bersosialisasi dan melepas kepenatan dari rutinitas sehari- hari.

Pada pusat perbelanjaan, air yang telah digunakan tidak boleh langsung dibuang ke lingkungan karena banyak mengandung bahan pencemar yang berbahaya sehingga menyebabkan pencemaran air. Dengan demikian pengolahan air limbah yang dihasilkan harus direncanakan dan dilaksanakan dengan baik.

Pada umumnya penduduk memenuhi kebutuhan akan air dengan cara membuat sumur. Akan tetapi, seperti yang kita ketahui bahwa kualitas air sumur di Jakarta sudah tidak memenuhi standar baku mutu air bersih. Oleh karena itu sebagian besar penduduk di Jakarta memilih menggunakan jasa perusahaan air bersih sebagai perusahaan komersil yang mengelola air bersih. Masyarakat Jakarta harus menghadapi kenyataan bahwa tarif air Perusahaan Daerah Air Minum(PDAM) akan dinaikkan sekitar 10-20\% mulai bulan Januari tahun 2007. Untuk mengatasi masalah tersebut maka masyarakat mencari jalan keluar dengan berbagai alternatif, salah satunya adalah dengan cara mendaur ulang air limbah yang dihasilkan dari kegiatan masyarakat. Sekarang ini telah banyak gedung-gedung perkantoran, hotel maupun pusat perbelanjaan yang telah melakukan proses daur ulang air limbah. Hal ini terbukti dapat menekan biaya untuk kebutuhan air bersih dari perusahaan komersil. Air baku yang dihasilkan dari proses daur ulang biasanya dapat digunakan untuk air penggelontor (flushing), menyiram tanaman, hydrant dan lain-lain. 
Sebagai pusat perbelanjaan yang cukup berkembang Plaza Slipi Jaya juga mendapat pengaruh dari kenaikan tarif air bersih tersebut. Pengelola harus berusaha memenuhi kebutuhan air bersih dan menekan biaya serta dapat memberikan pelayanan yang maksimal bagi para pengunjung Plaza Slipi Jaya. Salah satu yang dapat dilakukan adalah dengan mengurangi penggunaan air PDAM untuk kegiatan selain memasak atau untuk dikonsumsi oleh orang. Skripsi ini akan menguraikan tentang perencanaan sistem daur ulang air limbah non kakus di Plaza Slipi Jaya, dengan menentukan teknologi yang digunakan kemudian merencanakan atau menghitung dimensi dari teknologi yang telah dipilih. Perencanaan ini akan menyajikan neraca air, yang didalamnya terdapat keseimbangan antara kebutuhan air dengan hasil dari daur ulang tersebut. Dengan demikian diharapkan dapat memberikan gambaran bagi pengelola untuk dapat mempertimbangkan hasil dari perencanaan ini.

Di Plaza Slipi Jaya air limbah yang berasal dari dapur dan air hujan dialirkan tersendiri. Setiap hari Plaza Slipi Jaya membutukan air dari PDAM sebanyak $147 \mathrm{~m}^{3}$. Jadi Plaza Slipi Jaya membayar ke PDAM dengan harga yang relatif mahal. Walaupun perencanaan ini pada awalnya membutuhkan biaya dan pertimbangan yang baik, akan tetapi teknologi ini akan lebih menguntungkan dalam jangka panjang ke depan.

Air yang akan didaur ulang adalah limbah dari dapur (restoran), wastafel, dan tempat wudlu sebanyak $70,1 \mathrm{~m}^{3}$. Hal ini dilakukan agar proses daur ulangnya tidak memerlukan teknologi yang cukup tinggi dan diharapkan dapat menekan penggunaan air bersih yang berasal dari perusahaan air komersil. Karakteristik air yang akan didaur ulang hampir sama dengan air limbah non kakus yang berasal dari rumah tangga, maka teknologi yang digunakan akan lebih sederhana. Pada skripsi ini teknologi yang digunakan adalah sesuai dengan teori dan penelitian yang pernah dilakukan oleh Warjiyo,ST dan Amalia,SPd.

\section{METODA}

Tujuan dalam perencanaan ini adalah untuk mengetahui tentang teknologi apa yang sesuai untuk daur ulang air limbah non kakus pada pusat perbelanjaan, khususnya di Plaza Slipi Jaya. 
Perencanaan ini dapat dipertimbangkan oleh pihak pengelola dalam mengurangi penggunaan air PDAM.

Tempat perencanaan dilakukan di Plaza Slipi Jaya Jalan S. Parman Kavling 17-18 Jakarta Barat. Adapun waktu pelaksanaan dari Maret sampai dengan Juni 2007.

Metode perencanaan adalah dengan melakukan teknik survei lapangan dan studi literatur. Pelaksanaan survei adalah tentang :

1. Sistem pengolahan limbah yang ada selama ini di Plaza Slipi Jaya

2. Data-data real saat ini mengenai hasil limbah non kakus di Plaza Slipi Jaya yang dibutuhkan untuk perencanaan.

Teknik pengumpulan data yang digunakan sebagai parameter untuk memilih sistem dan perencanaan dengan menggunakan dokumentasi dan pedoman observasi. Dalam pedoman observasi tersebut ditulis data-data yang dibutuhkan dari Plaza Slipi Jaya atau instansi yang terkait.

Teknik perencanaan yang dipakai untuk memilih sistem daur ulang air limbah non kakus sesuai dengan teori-teori yang ada. Selain itu penulis menggunakan pedoman lain yaitu hasil penelitian yang pernah dilakukan sebelumnya oleh Warjiyo,ST dan Amalia,SPd dengan judul "Instalasi Pengolahan Air Limbah Rumah Tangga Non Kakus Untuk Keperluan MCK Pada Daerah Yang Mengalami Kekeringan Air".

\section{HASIL DAN PEMBAHASAN}

\section{A. Deskripsi Data}

\section{Kebutuhan Air Plaza Slipi Jaya Secara Teoretis}

Perhitungan kebutuhan air ini berdasarkan buku "Wastewater Engineering Treatment Disposal Reuse" oleh Metcalf \& Eddy.
a) Pekerja Kantor
$=100$ orang $\times 55=5.500 \mathrm{ltr} / \mathrm{hari}$
b) Pegawai
$=1000$ orang $\times 40=40.000 \mathrm{Itr} / \mathrm{hari}$
c) Pengunjung
$=4000$ orang $\times 19$
$=76.000 \mathrm{Itr} / \mathrm{hari}$
d) Bioskop
$=300$ orang $\times 11$
$=3.300 \mathrm{Itr} / \mathrm{hari}$
e) Coffe Shop
$=100$ orang $\times 23$
$=2.300 \mathrm{Itr} / \mathrm{hari}$
f) Restoran
$=650$ orang $\times 30$
$=19.500 \mathrm{ltr} / \mathrm{hari}$
$=146.600 \mathrm{ltr} / \mathrm{hari}$ 
Kebutuhan air per hari Plaza Slipi Jaya secara teoritis adalah $146.600 \mathrm{Itr} / \mathrm{hari} \approx 147 \mathrm{~m}$ /hari. Kebutuhan air ini sesuai dengan kebutuhan air dari Plaza Slipi Jaya.

\section{Data Air Limbah Non Kakus}

Data air limbah non kakus yang akan didaur ulang dengan kapasitas $\pm 70,1 \mathrm{~m}^{3} / \mathrm{hari}$.
a) Wastafel
$=5100$ orang $\times 5$
$=25.500$ Itr/hari
b) Dapur
$=650$ orang $\times 30$
$=19.500 \mathrm{Itr} / \mathrm{hari}$
c) Coffe Shop
$=100$ orang $\times 23$
$=2.300 \mathrm{Itr} / \mathrm{hari}$
d) Tempat Wudlu
$=4$ unit $\times 300 \times 19$
$=22.800 \operatorname{tt} r /$ hari
Total air limbah non kakus
$=70.100 \mathrm{It} / \mathrm{hari}$

Total air limbah non kakus yang akan didaur ulang di Plaza Slipi Jaya adalah $70.100 \mathrm{Itr} / \mathrm{hari}$ $70,1 \mathrm{~m} 3 /$ hari. Perhitungan beban air limbah non kakus tersebut merupakan perhitungan beban maksimum untuk air limbah yang dihasilkan dari Plaza Slipi Jaya.

\section{Penggunaan Air Hasil Daur Ulang di Plaza Slipi Jaya}

Air hasil daur ulang air limbah non kakus di Plaza Slipi Jaya sudah memenuhi standar untuk digunakan sebagai air penggelontor (flushing), dan untuk menyiram tanaman.

Penggelontor ini digunakan selama 12 jam = 720 menit, sedangkan untuk menyiram tanaman dilakukan selama 1 jam = 60 menit. Jadi sesuai dengan tabel 2 Aliran Rata-rata Air Limbah Berbagai Macam Alat, didapat perhitungan sebagai berikut :
a) Penggelontor
$=720 \times 95$
$=68.400$ liter $/$ hari
b) Penyiram Tanaman
$=60 \times 19$
$=1.140$ liter/hari
Jumlah penggunaan air hasil daur ulang $=69.540$ liter/hari

Jadi total jumlah penggunaan air hasil daur ulang air limbah non kakus di Plaza Slipi Jaya sebanyak 69.540 liter/hari $\approx 70 \mathrm{~m}^{3} / \mathrm{hari}$.

\section{Teknologi Daur Ulang Air Limbah Non Kakus}

Teknologi daur ulang air limbah non kakus ditentukan setelah dilakukan pengujian kualitas air limbah non kakus dari Plaza Slipi Jaya.Pengujian kualitas air limbah ini dilakukan di 
Laboratorium Kimia Fakultas MIPA Universitas Indonesia. Di bawah ini adalah hasil pengujian kualitas air limbah non kakus di Plaza Slipi Jaya :

Tabel 7 Hasil Pengujian Air Limbah Non Kakus di Plaza Slipi Jaya

\begin{tabular}{|c|c|c|c|c|c|}
\hline No & Parameter & Satuan & $\begin{array}{c}\text { Maks yang } \\
\text { diperbolehkan }\end{array}$ & $\begin{array}{c}\text { Hasil } \\
\text { Pengujian }\end{array}$ & Ket \\
\hline 1 & BOD & $\mathrm{Mg} / \mathrm{l}$ & 12 & 42,7 & berlebih \\
\hline 2 & COD & $\mathrm{Mg} / \mathrm{l}$ & 100 & 51,2 & \\
\hline 3 & TSS & $\mathrm{Mg} / \mathrm{l}$ & 400 & 383 & \\
\hline
\end{tabular}

Tempat pengujian : Laboratorium FMIPA Universitas Indonesia

Dari hasil pengujian diatas maka dapat ditentukan teknologi yang akan digunakan untuk mendaur ulang air limbah non kakus di Plaza Slipi Jaya yang terdiri dari bak penampung air limbah, bak saringan kasar, bak koagulasi, bak flokulasi, bak sedimentasi dan bak filtrasi serta bak penampung air hasil daur ulang.

Air limbah non kakus dari Plaza Slipi Jaya berasal dari dapur, wastafel, coffe shop dan tempat wudlu. Air limbah yang berasal dari dapur sebelumnya sudah melalui perangkap lemak yang terdapat pada peralatan mencuci dari dapur, akan tetapi pada kenyataannya masih terdapat minyak dan lemak.

Sebelum memasuki bak-bak pengolah atau bak daur ulang, air limbah non kakus ditampung terlebih dahulu pada bak penampung air limbah, untuk selanjutnya dialirkan ke bak saringan kasar, dengan adanya saluran yang menghubungkan langsung ke bak selanjutnya. Jadi Proses ini tidak membutuhkan pompa-pompa. Demikian pula pada proses selanjutnya. Sedangkan untuk mengalirkan atau mendistribusikan air bersih hasil daur ulang yang ditampung di bak effluent, digunakan pompa otomatis.

Pada bak pertama yang langsung berhubungan dengan bak penampung air limbah adalah bak saringan kasar. Dimana pada bak ini dipasang kawat penyaring untuk memisahkan sisa-sisa makanan dari dapur dan sampah lainnya sehingga tidak akan mengganggu proses selanjutnya. Dari bak ini diharapkan zat-zat padat sudah terpisah dari air limbah.. 
Bak kedua merupakan bak pembubuhan koagulan. Koagulan yang dipakai berupa kapur sebanyak 20 gram per 200 liter air. Pemilihan kapur ini dikarenakan mudah didapat dan harganya relatif murah. Kapur yang dibubuhkan ini dicairkan terlebih dahulu, kemudian dicampurkan pada air limbah yang sudah tidak mengandung zat-zat padat sisa makanan. Tujuan dari pembubuhan koagulan ini adalah untuk mengikat zat kimia terlarut dari sabun atau detergen. Dengan koagulan ini, zat-zat kimia yang berasal dari sabun akan diikat oleh zat koagulan sehingga terpisah dengan air murninya.

Bak ketiga berupa bak flokulasi. Di mana pada bak flokulasi ini dilakukan pengadukan untuk mendapatkan ukuran yang optimum dari partikel-partikel flok sehingga dapat disaring. Karena zat-zat padat mengambang yang dibuang dengan proses ini mengandung kadar zat organik yang tinggi, pembutiran juga mengarah ke terjadinya pengurangan dalam BOD. Setelah melalui proses koagulasi dan flokulasi diharapkan BOD akan berkurang sebanyak $65 \%$. Dengan demikian dapat diperhitungkan besarnya BOD yang dapat dihilangkan sebanyak :

$65 \% \times 42,7 \mathrm{mg} / \mathrm{l}=27,76 \mathrm{mg} / \mathrm{l}$

$$
\text { Sisa } \mathrm{BOD}=42,7 \mathrm{mg} / \mathrm{l}-27,76 \mathrm{mg} / \mathrm{l}=14,94 \mathrm{mg} / \mathrm{l}
$$

Bak keempat merupakan bak sedimentasi atau bak pengendapan. Bak ini berfungsi untuk memisahkan minyak/lemak dan mengendapkan lumpur yang masih tersisa dari bak sebelumnya. Bahkan pada penelitian yang dilakukan oleh Warjiyo,ST dan Amalia,SPd, setelah melewati bak sedimentasi kekeruhan air limbah ini berkurang, bahkan air limbah rumah tangga non kakus sudah terlihat jernih. Pada proses ini diharapkan dapat menghilangkan sisa BOD sebesar $40 \%$. Dengan demikian dapat diperhitungkan besarnya BOD yang dapat dihilangkan sebanyak :

$$
\begin{aligned}
& 40 \% \times 14,94 \mathrm{mg} / \mathrm{l}=5,98 \mathrm{mg} / \mathrm{l} \\
& \text { Sisa BOD }=14,94 \mathrm{mg} / \mathrm{l}-5,98 \mathrm{mg} / \mathrm{l}=8,96 \mathrm{mg} / \mathrm{l}
\end{aligned}
$$

Bak kelima merupakan bak filtrasi yaitu pengolahan air yang berasal dari bak sedimentasi. Pada bak ini juga diisi dengan bahan-bahan penyaring yang terdiri dari pasir halus, kerikil kasar dan kerikil halus serta ijuk. Adapun urutan penempatan bahan penyaring adalah sebagai berikut :

- Lapisan paling bawah berupa pasir halus setebal $70 \mathrm{~cm}$ 
- Lapisan di atas pasir adalah kerikil halus dengan diameter 3-8 mm tebal $50 \mathrm{~cm}$

- Lapisan paling atas berupa kerikil kasar diameter $\pm 12 \mathrm{~mm}$ tebal $50 \mathrm{~cm}$.

Sebelum digunakan untuk penyaringan, pasir dan kerikil harus dicuci terlebih dahulu sampai bersih. Pasir dan kerikil yang digunakan terus menerus untuk menyaring limbah rumah tangga non kakus, lama-lama dapat tersumbat dan akhirnya pasir dan kerikil ini sudah tidak dapat menyaring air limbah lagi. Oleh karena itu bahan-bahan penyaring yang terdiri dari pasir dan kerikil, setiap bulan harus dilakukan pencucian. Setelah satu bulan bahan-bahan penyaring ini sudah tidak efektif lagi dalam menyaring air limbah, karena tertutup oleh minyak/lemak dan lumpur halus yang terbawa air limbah.

Setelah melalui proses filtrasi maka air dialirkan ke bak effluent atau bak penampung air hasil daur ulang dan dibubuhhi kaporit untuk menyempurnakan hasil daur ulang, untuk kemudian dimanfaatkan sebagai air penggelontor (flushing), penyiram tanaman dan hidran.

\section{B. Perencanaan Daur Ulang Air Limbah Non Kakus}

Air limbah non kakus yang akan didaur ulang : 70,1 $\mathrm{m}^{3}$.

Waktu Pengolahan : 12 jam

Maka persentase banyaknya air yang diolah per jam : 100\%/12 = 8,33\%

Tabel 8. Persentase Pemakaian Air pada Plaza Slipi Jaya

\begin{tabular}{|c|r|r|c|}
\hline Jam Pemakaian & \% Pemakaian & Total \% Pemakaian & Kelebihan/kekurangan \\
\hline $09.00-12.00$ & 2,5 & 7,5 & $-17,49$ \\
$12.00-17.00$ & 13,5 & 67,5 & $+25,85$ \\
$17.00-19.00$ & 7 & 14 & $-2,66$ \\
$19.00-21.00$ & 5,5 & 11 & $-5,66$ \\
\hline
\end{tabular}

Jadi kelebihan air : $25,85 \%$

Debit air limbah $(Q) \quad=25,85 \% \times 70,1 \mathrm{~m}^{3}$

$$
=18,12 \mathrm{~m}^{3} / \mathrm{jam}
$$




\section{Bak Penampung Air Limbah}

Q $\quad=18,12 \mathrm{~m}^{3} / \mathrm{jam}$

Standar waktu tinggal $(\mathrm{td})=1 \mathrm{jam}$

Volume $\quad=Q \times$ td

$$
\begin{aligned}
& =18,12 \mathrm{~m}^{3} / \mathrm{jam} \times 1 \mathrm{jam} \\
& =18,12 \mathrm{~m}^{3} / \mathrm{jam}
\end{aligned}
$$

Dimensi Bak :

Tinggi Air $(\mathrm{H}) \quad=5 \mathrm{~m}$

$A=$ Volume $/ H=18,12 / 5=3,62 \mathrm{~m}^{3}$

$P: L=2: 1$

$2 \mathrm{LXL}=3,62 \mathrm{~m}^{2}$

$\mathrm{L} \quad=1,81 \mathrm{~m} \approx 2 \mathrm{~m}$

$\mathrm{P} \quad=2 \mathrm{~L} \quad=4 \mathrm{~m}$

Jadi dimensi bak :

Panjang $(\mathrm{P}) \quad: 4 \mathrm{~m}$

Lebar (L) : : $2 \mathrm{~m}$

Tinggi air $(\mathrm{H}) \quad: 5 \mathrm{~m}$

Tinggi bak $: 5+0,5: 5,5 \mathrm{~m}$

\section{Bak Saringan Kasar}

$\mathrm{Q}=18,12 \mathrm{~m}^{3} / \mathrm{jam}$

Standar waktu tinggal $(\mathrm{td})=0,5 \mathrm{jam}$

Volume $\quad=Q \times$ td

$$
\begin{aligned}
& =18,12 \mathrm{~m}^{3} / \mathrm{jam} \times 0,5 \mathrm{jam} \\
& =9,06 \mathrm{~m}^{3} / \mathrm{jam}
\end{aligned}
$$

Dimensi Bak :

Tinggi Air $(\mathrm{H})=3,5 \mathrm{~m}$

$A=$ Volume $/ H=9,06 / 3,5=2,59 \mathrm{~m}^{3}$

$P: L=2: 1$

$2 \mathrm{~L} X \mathrm{~L}=2,59 \mathrm{~m}^{2}$ 
$\mathrm{L} \quad=1,295 \mathrm{~m} \approx 1,3 \mathrm{~m}$

$P \quad=2 L \quad=2,6 m$

Jadi dimensi bak :

Panjang $(\mathrm{P}) \quad: 2,6 \mathrm{~m}$

Lebar $(\mathrm{L}) \quad: 1,3 \mathrm{~m}$

Tinggi air $(\mathrm{H}) \quad: 3,5 \mathrm{~m}$

Tinggi bak $: 3,5+0,5: 4 \mathrm{~m}$

\section{Koagulasi}

Q $\quad=18,12 \mathrm{~m}^{3} / \mathrm{jam}$

Standar waktu tinggal (td) $=1$ jam

Volume $\quad=Q \times$ td

$$
\begin{aligned}
& =18,12 \mathrm{~m}^{3} / \mathrm{jam} \times 1 \mathrm{jam} \\
& =18,12 \mathrm{~m}^{3} / \mathrm{jam}
\end{aligned}
$$

Dimensi Bak :

Tinggi Air $(\mathrm{H}) \quad=5 \mathrm{~m}$

$A=$ Volume $/ H=18,12 / 5=3,62 \mathrm{~m}^{3}$

$P: L \quad=2: 1$

$2 \mathrm{LXL}=3,62 \mathrm{~m}^{2}$

$\mathrm{L} \quad=1,81 \mathrm{~m} \approx 2 \mathrm{~m}$

$\mathrm{P}=2 \mathrm{~L} \quad=4 \mathrm{~m}$

Jadi dimensi bak :

Panjang (P) $\quad: 4 \mathrm{~m}$

Lebar (L) : $\quad: 2 \mathrm{~m}$

Tinggi air $(\mathrm{H}) \quad: 5 \mathrm{~m}$

Tinggi bak $: 5+0,5: 5,5 \mathrm{~m}$

\section{Bak flokulasi}

$\mathrm{Q} \quad=18,12 \mathrm{~m}^{3} / \mathrm{jam}$

Standar waktu tinggal (td) $=1$ jam

Volume $\quad=Q \times$ td

$=18,12 \mathrm{~m}^{3} / \mathrm{jam} \times 1 \mathrm{jam}$

$=18,12 \mathrm{~m}^{3} / \mathrm{jam}$ 
Dimensi Bak :

Tinggi Air $(\mathrm{H})=5 \mathrm{~m}$

$A=$ Volume $/ H=18,12 / 5=3,62 \mathrm{~m}^{3}$

$P: L=2: 1$

$2 \mathrm{LXL}=3,62 \mathrm{~m}^{2}$

$\mathrm{L} \quad=1,81 \mathrm{~m} \approx 2 \mathrm{~m}$

$\mathrm{P} \quad=2 \mathrm{~L} \quad=4 \mathrm{~m}$

Jadi dimensi bak:

Panjang $(\mathrm{P}) \quad$ : $4 \mathrm{~m}$

Lebar (L) : $2 \mathrm{~m}$

Tinggi air $(\mathrm{H}) \quad: 5 \mathrm{~m}$

Tinggi bak : $5+0,5: 5,5 \mathrm{~m}$

\section{Bak Sedimentasi}

$\mathrm{Q} \quad=18,12 \mathrm{~m}^{3} / \mathrm{jam}$

Standar waktu tinggal $(\mathrm{td})=2-6 \mathrm{jam}$

Volume $\quad=Q \times$ td

$$
\begin{aligned}
& =18,12 \mathrm{~m}^{3} / \mathrm{jam} \times 4 \mathrm{jam} \\
& =72,48 \mathrm{~m}^{3} / \mathrm{jam}
\end{aligned}
$$

Dimensi Bak :

Tinggi Air $(\mathrm{H}) \quad=7,5 \mathrm{~m}$

$A=$ Volume $/ H=72,48 / 7,5=9,66 \mathrm{~m}^{3}$

$P: L \quad=2: 1$

$2 \mathrm{LXL}=9,66 \mathrm{~m}^{2}$

$\mathrm{L} \quad=4,83 \mathrm{~m}$

$P \quad=2 L \quad=9,66 \mathrm{~m}$

Jadi dimensi bak :

Panjang $(P) \quad: 9,66 \mathrm{~m} \approx 10 \mathrm{~m}$

Lebar $(\mathrm{L}) \quad: 4,83 \mathrm{~m} \approx 5 \mathrm{~m}$

Tinggi air $(\mathrm{H}) \quad: 7,5 \mathrm{~m}$ 
Tinggi bak $\quad: 7,5+0,5: 8 \mathrm{~m}$

\section{Bak Filtrasi}

Q $\quad=18,12 \mathrm{~m}^{3} / \mathrm{jam}$

Standar waktu tinggal (td) $=4$ jam

Volume $\quad=Q \times$ td

$$
\begin{aligned}
& =18,12 \mathrm{~m}^{3} / \mathrm{jam} \times 4 \mathrm{jam} \\
& =72,48 \mathrm{~m}^{3} / \mathrm{jam}
\end{aligned}
$$

Dimensi Bak :

Tinggi Air $(\mathrm{H}) \quad=7,5 \mathrm{~m}$

$A=$ Volume $/ H=72,68 / 7,5=9,66 \mathrm{~m}^{3}$

$P: L \quad=2: 1$

$2 \mathrm{LXL}=9,66 \mathrm{~m}^{2}$

$\mathrm{L} \quad=4,83 \mathrm{~m}$

$P \quad=2 L \quad=9,66 \mathrm{~m}$

Jadi dimensi bak :

Panjang $(P) \quad: 9,66 m \approx 10 m$

Lebar $(\mathrm{L}) \quad: 4,83 \mathrm{~m} \approx 5 \mathrm{~m}$

Tinggi air $(\mathrm{H}) \quad: 7,5 \mathrm{~m}$

Tinggi bak $: 7,5+0,5: 8 \mathrm{~m}$

\section{Bak Effluent (bak penampung air hasil olahan)}

$\mathrm{Q} \quad=18,12 \mathrm{~m}^{3} / \mathrm{jam}$

Standar waktu tinggal (td) $=12$ jam

Volume $\quad=\mathrm{Q} x \mathrm{td}$

$$
\begin{aligned}
& =18,12 \mathrm{~m} 3 / \mathrm{jam} \times 12 \mathrm{jam} \\
& =217,44 \mathrm{~m}^{3} / \mathrm{jam}
\end{aligned}
$$

Dimensi Bak :

Tinggi Air $(\mathrm{H}) \quad=12 \mathrm{~m}$

$A=$ Volume $/ H=217,44 / 12=18,12 \mathrm{~m}^{3}$

$P: L \quad=2: 1$

$2 \mathrm{LXL}=18,12 \mathrm{~m}^{2}$ 
$\mathrm{L} \quad=9,06 \mathrm{~m} \approx 9 \mathrm{~m}$

$P \quad=2 L \quad=18 \mathrm{~m}$

Jadi dimensi bak :

Panjang $(\mathrm{P}) \quad: 18 \mathrm{~m}$

Lebar $(\mathrm{L}) \quad$ : $9 \mathrm{~m}$

Tinggi air $(\mathrm{H}) \quad: 12 \mathrm{~m}$

Tinggi bak $\quad: 12+0,5: 12,5 \mathrm{~m}$

\section{Perhitungan Kebutuhan Kaporit}

Berdasarkan buku Metcalf \& Eddy, "Wastewater Engineering Treatment, Disposal \& Reuse", perhitungan kebutuhan kaporit adalah :

- Kapasitas air limbah yang mengalir $=18,12 \mathrm{~m} 3 / \mathrm{jam}$

- Syarat kadar khlorin yang dibutuhkan = $2 \mathrm{mg} / \mathrm{l}$

- Kebutuhan khlorin setiap hari

$$
\begin{aligned}
=2 \mathrm{mg} / \mathrm{l} \times(18,12 \mathrm{~m} 3 / \mathrm{jam} \times 24 \times 2,6417 \times 0,0001) \times[8,349 \mathrm{lb} / \mathrm{mgal}) .(\mathrm{mg} / \mathrm{l})] \\
=1,92 \mathrm{Lb} / \text { hari } \quad=1,92 \times 4,5359 \times 100 \\
=870,89 \mathrm{gr} / \text { hari }
\end{aligned}
$$

- Kebutuhan Khlorin tiap jam = 870,89 : $24=36,29 \mathrm{gr} / \mathrm{jam}$

\section{Hasil Perencanaan}

Dilihat dari kebutuhan air dari Plaza Slipi Jaya, jumlah air limbah non kakus dan penggunaan air hasil daur ulang dapat disimpulkan bahwa dengan adanya daur ulang air limbah ini akan mengurangi penggunaan air dari Perusahaan Daerah Air Minum (PDAM) sebanyak 47,69 \%.

Dikarenakan hasil dari pengujian air limbah non kakus di Plaza Slipi Jaya yang tidak memenuhi standar baku mutu kualitas air kelas IV adalah parameter BOD, sedangkan yang lainnya masih dalam batas aman maka yang lebih diperhitungkan adalah BODnya. Dari hasil analisa BOD dapat dikurangi hingga mencapai $8,96<12 \mathrm{mg} / \mathrm{l}$ (sudah memenuhi standar).

Walaupun demikian, untuk parameter COD dan TSS dapat diasumsikan sebagai berikut :

- Influent COD : 51,2 mg/l

Asumsi pengurangan COD : $51,2 \times 40 \%: 20,48 \mathrm{mg} / \mathrm{l}$

Persepsi Tenaga Ahli Jasa Konstruksi Terhadap Penyelenggaraan Sertifikasi Oleh Unit Sertifikasi Tenaga Kerja Lembaga Pengembangan Jasa Konstruksi 
Jadi Efluent COD : $51,2 \mathrm{mg} / \mathrm{l}-20,48 \mathrm{mg} / \mathrm{l}: 30,72 \mathrm{mg} / \mathrm{l}$

- Influent TSS : $383 \mathrm{mg} / \mathrm{l}$

Asumsi pengurangan TSS : $383 \times 70 \%: 268,1 \mathrm{mg} / \mathrm{l}$

Jadi Efluent TSS : $383 \mathrm{mg} / \mathrm{l}-268,1 \mathrm{mg} / \mathrm{l}: 114,9 \mathrm{mg} / \mathrm{l}$

Dari hasil analisa di atas maka dapat diambil kesimpulan bahwa air hasil daur ulang ini memenuhi standar baku mutu kualitas air kelas IV yang dapat digunakan sebagai penyiram tanaman maupun penggelontor. Air hasil daur ulang ini belum dapat digunakan sebagai air baku untuk air minum.

Selain itu berdasarkan hasil penelitian dari Warjiyo, ST dan Amalia, M. Pd didapatkan hasil dari daur ulang air limbah non kakus sebagai berikut :

Tabel 9. Hasil Penelitian Daur Ulang Air Limbah Non Kakus oleh warjiyo, ST dan Amalia, M.Pd

\begin{tabular}{|c|l|c|c|r|l|}
\hline No & \multicolumn{1}{|c|}{ Parameter } & Satuan & $\begin{array}{r}\text { Maks yang } \\
\text { diperbolehkan }\end{array}$ & $\begin{array}{r}\text { Hasil } \\
\text { Pengujian }\end{array}$ & Keterangan \\
\hline 1 & $\mathrm{pH}$ & - & 9,2 & 6,02 & \\
\hline 2 & $\mathrm{KmnO}_{4}$ & $\mathrm{Mg} / \mathrm{l}$ & 10 & 8,77 & \\
\hline 3 & $\mathrm{CO}_{2}$ & $\mathrm{Mg} / \mathrm{l}$ & 0 & 107,36 & Berlebih \\
\hline 4 & $\mathrm{CaCO}$ & & 109,94 & \\
\hline 5 & $\mathrm{Ca}$ & $\mathrm{Mg} / \mathrm{l}$ & 500 & 88,67 & \\
\hline 6 & $\mathrm{Mg}$ & $\mathrm{Mg} / \mathrm{l}$ & 200 & 21,33 & \\
\hline 7 & $\mathrm{Fe}$ & $\mathrm{Mg} / \mathrm{l}$ & 150 & 0,398 & \\
\hline 8 & $\mathrm{Mn}$ & $\mathrm{Mg} / \mathrm{l}$ & 0,5 & 0,089 & \\
\hline 9 & $\mathrm{Cl}$ & $\mathrm{Mg} / \mathrm{l}$ & 600 & 42,57 & \\
\hline 10 & Sulphat & $\mathrm{Mg} / \mathrm{l}$ & 400 & 179,2 & \\
\hline 11 & $\mathrm{Nitrit}$ & $\mathrm{Mg} / \mathrm{l}$ & 1 & 0,045 & \\
\hline
\end{tabular}

Dari data di atas terlihat bahwa sifat kimia air hasil daur ulang yang tidah memenuhi syarat adalah kadar karbondioksida bebas yang masih tinggi. Karena kadar $\mathrm{CO}_{2}$ yang masih tinggi ini, maka air hasil daur ulang belum memenuhi syarat sebagai air minum. 


\section{Kelemahan Perencanaan}

1. Pada proses daur ulang air limbah non kakus ini membutuhkan tenaga kerja yang lebih untuk selalu mamantau proses daur ulang ini.

2. Membutuhkan lahan yang cukup luas.

\section{KESIMPULAN}

Berdasarkan hasil perencanaan maka dapat ditarik kesimpulan sebagai berikut :

1. Daur ulang air limbah non kakus merupakan salah satu usaha untuk mengurangi penggunaan air dari PDAM di Pusat Perbelanjaan Plaza Slipi Jaya sehingga dapat menekan biaya serta menguntungkan dalam jangka panjang.

2. Daur ulang air limbah non kakus dapat mengurangi penggunaan air dari PDAM sebanyak $47,69 \%$.

3. Hasil perencanaan daur ulang air limbah non kakus di Plaza Slipi Jaya berupa dimensi dari bak-bak yaitu : bak saringan kasar, bak koagulasi, bak flokulasi, bak sedimentasi dan bak filtrasi serta bak penampung air hasil daur ulang.

4. Daur ulang air limbah non kakus ini dapat mengurangi konsentrasi BOD 79,02 \%, COD $40 \%$ dan TSS $70 \%$. Air hasil daur ulang ini mengandung BOD sebanyak 8,92 mg/l, COD sebanyak 30,72 mg/l dan TSS sebanyak 114,9 mg/l. Dari Uraian tersebut maka dapat disimpulkan bahwa air hasil daur ulang ini sudah memenuhi standar mutu kualitas air kelas IV menurut Peraturan Pemerintah No. 82 Thn 2001 tentang Pengelolaan Kualitas Air dan Pengendalian Pencemaran Air, sehingga dapat digunakan sebagai penggelontor (flushing) dan penyiram tanaman .

5. Daur ulang ini membutuhkan pompa-pompa otomatis pada setiap baknya sehingga lebih mempermudah proses pengolahan air limbah non kakus.

\section{DAFTAR PUSTAKA}

Amos, Janine. Mengenal IImu : Limbah dan Daur Ulang. London : Watts Book, 2001.

Departemen Pekerjaan Umum. Pedoman perencanaan hidrologi dan Hidraulik untuk Bangunan di Sungai. Jakarta : Yayasan Badan Penerbit PU, 1987. 
Departemen Permukiman dan Prasarana Wilayah. Petunjuk Teknis (Pt - T-16 - $2002-C)$ :

Tata Cara Pengelolaan Air Limbah Non Kakus (Grey Water). Bandung : Departemen Permukiman dan Prasarana Wilayah, 2001.

Hendargo, Iman. Kamus Istilah Lingkungan. Jakarta : Bina Rena Pariwara, 1994.

Hindarko, S. Mengolah Air Limbah Supaya Tidak Mencemari Orang Lain. Jakarta : ESHA, 2003.

http://www. Kerinci.org/ipsp/Bab3, html. Perencanaan Tata Ruang.

Kompas. www.kompas.com. Mendaur Ulang Air dengan Instalasi Mini. Tanggal Cetak 14 Agustus 2002.

Mara, Duncan. Pemanfaatan Air Limbah dan Ekskreta. Bandung : ITB, 1994.

Marhiyanto, Bambang. Kamus Lengkap Bahasa Indonesia. Surabaya : Media Centre.

Metcalf \& Eddy. Wastewater Engineering Treatment Disposal Reuse. Mc. Graw Hill : Edisi II. 1991.

Sidharta S. K. Rekayasa Lingkungan. Jakarta : Gunadarma. 1997.

Soeharto, Imam. Manajemen Proyek dari Konseptual Sampai Operasional. Jakarta : Erlangga, 1999

Sugiharto. Dasar-dasar Pengolahan Air Limbah. Jakarta : UI Press, 1987.

Sutoro, Aris. Meminimalkan Air Buangan Pada Gedung Bertingkat dengan Proses Daur Ulang Berdasarkan Analisa Teknis, Biaya dan Manfaat. Jakarta : FTSP UPI YAI, 2002.

Warjiyo \& Amalia, Instalasi Pengolahan Air Limbah Rumah Tangga Non Kakus untuk Keperluan MCK pada Daerah yang Mengalami Kekeringan Air. Jakarta : Politeknik Negeri Jakarta, 2002. 